\title{
Confronting perceptions of student equity in higher education
}

\author{
Trevor Gale $\cdot$ Sam Sellar
}

Published online: 27 February 2011

(C) The Australian Association for Research in Education, Inc. 2011

This special issue of the Australian Educational Researcher brings together a collection of papers 'Confronting Perceptions of Student Equity in Higher Education.' It speaks to a conversation within and between the United Kingdom and Australia about student equity policy in higher education, which has been ongoing at least since the Second World War (Gale and Tranter 2011). The papers in this issue have emerged out of a particular moment in this conversation, in which student equity has resurfaced on the Australian higher education policy landscape following an extended period of silence. At the same time student equity is entering an uncertain period in the UK's higher education environment, following an extended period of relatively successful yet unfinished 'widening participation' (Higher Education Funding Council for England (HEFCE) 2010). The current moment is also characterised by: (a) the ongoing effects of the global financial crisis, which have been differently negotiated and experienced by the UK and Australia, with different implications for student equity policy; (b) a general shift within OECD nations from mass to near universal higher education systems (Trow 1974, 2006), aimed at increasing their competitiveness in the global knowledge economy; and by (c) the globalisation of the field of higher education, spurred on by the increasing importance of Times Higher Education Supplement and Shanghai Jiao Tiong league tables, the creation of and reactions to a 'European Higher Education Area' (European Ministers of Education 1999), and increasing flows of university students across national borders (Marginson 2008; Varghese 2008).

In this policy moment, student equity is a confronting ideal for higher education. Similarly, the changing field of higher education is challenging previous perceptions of what constitutes student equity. These 'confrontations' and 'perceptions' form the parameters of the papers in this special issue. Collectively, they argue that the globalisation of higher education draws attention to inequities in the field, which are

T. Gale $(\bowtie) \cdot$ S. Sellar

National Centre for Student Equity in Higher Education, Adelaide, Australia

e-mail: trevor.gale@unisa.edu.au 
beyond the purview of nation states, and to the inadequacy of a nation's higher education system as the denominator for calculating the proportional representation of marginalised groups (Gale, this issue). Yet nation states are not without influence. In Australia and the UK, for example, people from low socioeconomic backgrounds are now privileged in higher education policy discourse, such that gender equity is confined to the under-representation of young working class males (David, this issue), while people with disabilities have been displaced from policy debates altogether (Ryan, this issue). This privileging of socioeconomic status has raised the significance of methodological accuracy in its calculation (Sealey, this issue), which in turn informs the way in which equity is now conceived. This is evident in how Indigenous peoples and people from regional and rural areas are sidelined within current Australian Government policy, as little more than beneficiaries of 'steps to improve low SES student participation' (Australian Government 2009, p. 14). Similarly, David (this issue) argues that in the UK higher education system-and we would suggest in Australia as well-gender equity has lost its 'critical edge'.

The authors in this collection are also concerned with the ways in which institutional policies and practices create barriers for student equity (Ryan, this issue; Abbott-Chapman, this issue) and, hence, require transformative remediation. As Fraser explains:

By affirmative remedies for injustice I mean remedies aimed at correcting inequitable outcomes of social arrangements without disturbing the underlying framework that generates them. By transformative remedies, in contrast, I mean remedies aimed at correcting inequitable outcomes precisely by restructuring the underlying generative framework. The crux of the contrast is end-state outcomes versus the processes that produce them. (Fraser 1997, p. 23; emphasis added)

In these terms, an affirmative approach to student equity informs the Australian Government's statement on Transforming Australia's Higher Education System (2009). It aims to correct the inequitable representation of people from low SES backgrounds in the nation's universities; to put them in their 'rightful' place rather than restructure those places (Gale, this issue). Even taking account of the vertical stratification of institutions (Abbott-Chapman this issue) - ensuring the proportional representation of equity groups in elite institutions and courses, not just within the higher education system as a whole — can go only so far. Also needed is an account of the horizontal stratification of 'regions', which requires institutions and policies that are more responsive and reflexive (Abbott-Chapman this issue). Despite the long history of equity engagement in the UK and Australia, we are still some distance from such responsiveness and reflexivity. For example, Ryan (this issue) argues that academics' general ignorance of their equity responsibilities is often reflected in their negative attitudes towards students with disabilities, which translates into inequitable practices and course requirements. This extends to academics' perceptions of assessment practices, which are increasingly responsive to the marketisation of higher education but do not always reflect the needs of students (Goos, Gannaway and Hughes, this issue). In restructuring for student equity, David (this issue) argues for the development of critical and feminist-inspired 'connectionist' pedagogies, to 
transform the very nature of higher education for all students. Beckett (this issue) makes the case for these to be negotiated within professional learning communities, which transcend sector and institutional boundaries. It is in such communities that the knowledge work of transforming the means and, hence, the ends of higher education (and education more broadly) can most fruitfully take place.

In sum, the papers in this special issue argue for student equity defined in terms of the transformation of higher education. In the end, this is the most confronting aspect for higher education, particularly for those who have traditionally perceived equity as a numerical equation. Transforming the very nature of higher educationthe inclusion of particular forms of knowledge and ways of knowing - is far more than the diversification of the university student population and the 'beefing up' of support structures to accommodate this, which some anticipate and even fear. In raising these matters, we hope to move the conversation on, in particular, beyond the bifurcation of 'equity' and 'excellence' (Gale, this issue), which continues to position student equity as just out of reach. We look forward to seeing and being part of where this turn in the conversation may lead.

Acknowledgments The editors would like to thank all those who refereed the articles published in this special issue. Thanks also to Stephen Parker who greatly assisted us in managing the process of putting the issue together. The team is also very grateful for the support of Annette Patterson, the editor of AER. Thank you all for your time, energy and effort.

\section{References}

Australian Government. (2009). Transforming Australia's Higher Education System. Canberra: DEEWR. Retrieved 18 November 2010, from http://www.deewr.gov.au/HigherEducation/Documents/PDF/ Additional\%20Report\%20-\%20Transforming\%20Aus\%20Higher\%20ED_webaw.pdf.

European Ministers of Education. (1999). The Bologna Declaration of 19 June 1999. Retrieved 18 November 2010, from http://www.bologna-berlin2003.de/pdf/bologna_declaration.pdf.

Fraser, N. (1997). Justice Interruptus: Critical reflections on the "Postsocialist" condition. New York: Routledge.

Gale, T. \& Tranter, D. (2011). Social justice in Australian higher education policy: an historical and conceptual account of student participation. Critical Studies in Education, 52(1), 29-42.

Higher Education Funding Council for England (HEFCE). (2010). Trends in young participation in higher education: core results for England. Bristol: HEFCE. Retrieved 18 November 2010, from http://www.hefce.ac.uk/pubs/hefce/2010/10_03/.

Marginson, S. (2008). Global field and global imagining: bourdieu and worldwide higher education. British Journal of Sociology of Education, 29(3), 303-315.

Trow, M. (1974). Problems in the transition from elite to mass higher education. Policies for Higher Education (pp. 51-101). Paris: OECD.

Trow, M. (2006). Reflections on the transition from elite to mass to universal access: Forms and phases of higher education in modern societies since WWII. In J. J. F. Forrest \& P. G. Altbach (Eds.), International handbook of higher education, part one: global themes and contemporary challenges (pp. 243-280). Dordrecht: Springer.

Varghese, N.V. (2008). Globalization of higher education and cross-border student mobility. Paris: UNESCO. Retrieved 18 November 2010, from http://www.unesco.org/iiep/PDF/pubs/2008/ Globalization_HE.pdf. 